\title{
Research on the Current Situation and Strategy of Cyber Political Education in Universities
}

\author{
Yonghua Jing \\ Minsheng College \\ Henan University \\ Kaifeng, Henan, China 475004
}

\begin{abstract}
Carrying out the research on the present situation and the strategy of cyber political education in university has an important function in promoting the undergraduate's ideological and political quality. Taking this into view, therefore, a tentative study of related issues was carried out in this paper.
\end{abstract}

Keywords—university; cyber politics; education; current situation; strategy

\section{INTRODUCTION}

The channels through which undergraduates obtain information at present are quite different from those in the past. The traditional ones were mainly books, newspapers, magazines and so on. These traditional methods of information acquisition were slow in acquisition and were largely limited in content. The students' ideas were limited by the impact of the information. The Internet has changed all of these and become an important channel for undergraduates to get information. Its influence on them is far-reaching, therefore, it is imperative to carry out cyber political education in colleges and universities.

\section{NECESSITY ANALYSIS OF THE IMPLEMENTATION OF CYBER POLITICAL EDUCATION IN COLLEGES AND UNIVERSITIES}

Now it is the era of cyber explosion, with the information spreading on the Internet at faster speed, in more fields and more quantities. The information spread through Internet is a mess. Some are positive, while the others are negative. Undergraduates are at the important age for forging view of life and world outlook. The university period is full of youthful vitality. The Internet is attractive to undergraduate. They spend much more time on the Internet than other age group. Therefore, they are largely influenced by the cyber information. In this sense, the implementation of ideological and political education in Colleges and universities can not drift away from the network environment to carry out political education activities. In order to achieve the substantial results of political education in university, more importance must be attached to the implementation of cyber political education by taking the Internet as the important position of ideological and political education for undergraduates. Only in this way, can the implementation of ideological and political education in colleges and universities achieve the expected educational goal.

\section{THE FACTORS INFLUENCING THE ACTUAL EFFECTIVENESS OF CYBER POLITICAL EDUCATION IN UNIVERSITY}

\section{A. The Internet Development Advances Irresistibly}

It should be said that the Internet development history is not long, but since the day of the birth of the Internet, its development speed is overwhelming. It is an important platform for people to contact, communicate with each other, exchange and share information. The Internet has permeated into all areas of people's lives and changed their life style and thinking mode. Undergraduates are the fresh troops in application of Internet. Its application is very popular among undergraduate groups. It should be said that the Internet is the window and carrier for them to understand the society and the world. Their thoughts are deeply influenced by the Internet. Therefore, the rapid development of the Internet is an important factor that has impact on the actual effect of cyber political education in university.

\section{B. The Impact of Diversification Idea}

Since the reform and opening up, our country has opened its door which had been closed for a long time, so as to widen the field of vision of the Chinese people. All kinds of new things have emerged in an endless stream into every Chinese vision. The ideology from different races and countries across the world, as well as modern thoughts, are very popular everywhere in China. [1:73] Influenced by the trend of diversified thought, the undergraduates thinking development is also showing a diversified development trend, especially in the cyber, the information exchange platform, there are large amount of multi thoughts which have a great impact on the thinking of undergraduates. These are important factors that affect the effectiveness of the cyber political education in colleges and universities. In these diversified thoughts, there are progressive, healthy ideas, and negative ones as well. The progressive idea is positive in its influence to the undergraduate, while negative idea is negative in its influence. Therefore, in the implementation of cyber political education in colleges and universities, teachers have to face the impact of these diversified ideas 
and to promote undergraduates to form a correct outlook on life and on the world with active and healthy cyber political education so as to give play to its effectiveness. .

\section{Undergraduates' Thought Is Not Mature Enough}

The thoughts of undergraduates are not mature as they are limited by their age. The undergraduates always grow up in the campus, and have less contacted the outside world. Their social experience and social experience are relatively scarce. Especially, they are lack of lack of correct judgment on some bad ideas in society, and often are influenced by bad thoughts. The Internet is an open platform, with lots of sources of information. Some people with an ulterior motive make some irresponsible remarks on the Internet. The undergraduates cannot make an accurate and objective evaluation of these ultra remarks and they are often affected by these adverse remarks. It is one of the important factors that influence the cyber political education.

\section{The CURRENT Situation OF Cyber Political EDUCATION IN COLLEGES AND UNIVERSITIES}

\section{A. Relatively Simple Education Methods, Unsatisfactory Education Effect}

As far as the current cyber political education in colleges and universities is concerned, its implementation method is relatively simple at present, and its effect is not ideal. In analysis, the main reason is that at present, in the implementation of cyber political education in university, the trace and guidance are given to them on using the Internet through cyber tool. The guidance is the main way to carry out the cyber political education. But the tracing guidance method has its own limitations, while the Internet is open, but in hiding. As the individual using the Internet, this person uses the Internet with privacy. His actions are hardly discovered by others. Therefore, this case has greatly affected the effectiveness of cyber politics education done in university. This single mode of education has made the education effect very poor.

\section{B. Imperfect Legislation and System}

Whether the cyber environment is healthy or not is a great impact on the implementation of cyber political education in colleges and universities. It is the premise of the cyber political education in colleges and universities. The present cyber environment is not satisfactory, and it is required to be improved. Taking the quality of present netizens into consideration, presently, these netizens differ in quality. The Internet management measures are far from being perfect. Some bad contents, terror, violence and pornography and other negative information appear online. Such negative information, in a subtle influence, has a lot of negative impact on undergraduates. The current cyber information management legislation is not perfect, and its management system also needs to be further improved. This real environment of cyber political education brings considerable resistance to the cyber political education work in university to a certain extent, and is not conducive to the effective development of cyber political education in university. .

\section{IMPLEMENTING STRATEGY OF CYBER POLITICAL EDUCATION IN COLLEGES AND UNIVERSITIES}

\section{A. The Traditional Education Concept Shall Be Changed}

In the implementation of traditional political education in colleges and universities, teachers are leading actors in the implementation of the political education. Their education activities are the core of the political education, and the main position of students in the political education is not respected as they ought. The political education is carried out without paying attention to the real idea of students, nor to the requirements of students. Single and old-fashioned education method fails to meet the political education for undergraduates. Therefore, in the process of the implementation of cyber political education in colleges and universities, teachers should change their original educational ideas as early as possible, take the healthy development of students' ideas, combine the education with the characteristics of online education, pay attention to students' ideological education, carry out health education through the network platform so as to promote the healthy development of undergraduate thoughts.

\section{B. Give Legal Education to Undergraduates}

The complexity of Internet information cannot be resolved within one day. Such bad cyber information seriously abuses undergraduates' thoughts. As it is seen now, in the cyber political education, legal propaganda will be strengthened to help them to form a correct legal concept, which is an important means of reducing the negative impact of bad information. In the implementation of cyber political education, universities shall try to make use of internet platform to carry out targeted legal education combined with the reality of the Internet and the real life of students. In particular, the education on the related laws and regulations on the use of Internet shall be given in order to let the students know in the Internet environment what behavior is illegal, and what behavior is legal, and to enhance the students' correct judgment on the negative phenomena and negative information in the network environment, to cultivate students' legal system. This is the important way of carrying out internet political education effectively.

\section{Enhance the Attraction of Education Platform}

In some colleges and universities, some websites have been set up for the cyber political education aimed at undergraduates, with the purpose of helping them to use the Internet rationally, to guide and help them to develop correct thoughts in the cyber environment. Such purpose is good, hoping that the establishment of university political education website can better promote the effective development of cyber political education in colleges and universities. The most important is to strengthen the training of related technologies, to enhance the technical content of the websites, so as to build an attractive network platform to 
promote the efficient development of cyber political education.

\section{CONCLUSION}

Carrying out the research on the present situation and strategy of cyber political education in colleges and universities has a disregardful action in the promotion of effective internet political education. At present, there are many problems in the implementation of internet political education in colleges and universities. Therefore, it is of practical significance to propose some effective solutions.

\section{REFERENCES}

[1] Chen Xiaoyi The dilemma and solution research of ideological and political education network communication process management $[\mathrm{J}]$. Herald of Thoughts Theory Education 2010, (6): 71-74. 